Local wisdom
$\begin{aligned} & \text { LOCAL WISDOM, 11 (2): 138-145,2019 } \\ & \text { Local Wisdom Scientific Online Journal } \\ & \text { ISSN: 2086-3764 }\end{aligned}$

\title{
Visual Elements Influence at the Facade of Historical Buildings in Jalan Panglima Sudirman Corridor Batu, Indonesia
}

\author{
Budi Tri Wijaya ${ }^{1}$, Jenny Ernawati ${ }^{2}$, Herry Santosa ${ }^{2}$ \\ 1Magister of Architecture, University Of Brawijaya, Malang, Indonesia \\ 2Department Of Architecture, University Of Brawijaya, Malang, Indonesia \\ Corresponding Author: : buditriw888@gmail.com
}

$\begin{array}{ll}\text { Keywords: } & \text { Abstract } \\ \text { batu city, façade, } & \begin{array}{l}\text { The city of Batu is one of the colonial cities with enormous historical } \\ \text { historical } \\ \text { building, visual } \\ \text { element. }\end{array} \\ \text { become the city's cultural heritage. Jalan Panglima Sudirman is one of the } \\ \text { corridors having the most heritage, namely in the form of historic } \\ \text { buildings. The appearance of historic buildings often gives an interesting } \\ \text { visual impression on a street corridor. This study was to determine the } \\ \text { effect of visual elements on the facade of historical buildings based on } \\ \text { people's perceptions. Using quantitative methods, data were collected } \\ \text { through field surveys combined with questionnaires. Based on public } \\ \text { perception, it has been shown that the appearance of the facade of a } \\ \text { historic building is moderate to good. The architectural style and shape of } \\ \text { the historical buildings' facade are the most influential elements playing } \\ \text { an important role based on perceptions of shows that display facade } \\ \text { historic buildings to having the appearance of being good. A style of } \\ \text { architecture and visual form is the most influential elements of buildings } \\ \text { façade. These results were expected to be able to help the community and } \\ \text { government in the effort to develop the historic area. }\end{array}$

@ 2017 The Authors. Published by GKAK UNMER Malang

*Corresponding Author: buditriw888@gmail.com 


\section{Introduction}

Batu City is one of the colonial cities in Indonesia with great historical significance. It has many relics from the colonial period in the form of historic buildings and sites used as the cultural heritage of the city. Efforts made by the Batu city government to protect the heritage have been listed in the Batu City RTRW in 2010. Article 43 about the cultural heritage area includes historic ancient buildings. One of the most ancient buildings in Batu city can be found in Pesanggrahan village. Pesanggrahan village is a village with a history of former colonial occupation buildings in the past. Panglima Sudirman street is the most famous historic building compared to other streets in Pesanggrahan village. The selection of research locations was also supported by the presence of around 20 historic ancient buildings scattered in this corridor which serves as a main street in the past and present. According to Boedihardja et al. (2010) some ancient historic buildings with colonial architectural styles found on the Panglima Sudirman Batu street corridor, however, worsen in terms of their physical conditions and are less and less noticed.

The existence of historic buildings gives a visually attractive impression on an area. Visual impressions are closely related to the visual quality of these historic buildings. Visual quality is the result of a person's perception of the physical appearance of an object. It is different from the visual character, that discusses the character or identity of objects in an area. Visual is a display of an environment in the form of buildings and other elements that can be observed by viewing (Wibisono, 2008). Visual quality is an attribute of a visual system that can be determined by physical elements and cultural values (Kurniawan et al., 2017).

In an urban context, building facades possess an important role that can represent the character of a city. Building facades are expressions or representations of several physical aspects that can be observed and assessed visually (Kurniawan et al., 2017). The facade of the building is one of the elements of beauty from the front of the building that can be used as a characteristic reflecting the architectural style. In the research of Santosa et al. (2013), there were three architectural styles in his research, namely colonial, modern and Indonesian architectural styles. The colonial architectural style is characterized by horizontal and vertical shapes, flat roofs, and white paint. The architectural style and shape of the facade of the building directly or cannot convey cultural expressions and meanings when the building exists. Coeterier (in Askari and Kamariah, 2009) argues that finishing on facades makes a special attraction in a building, especially historic buildings. So some opinions can be used as an evaluation of the visual elements contained in the building facade.

Some studies regarding the visual quality of facades of historic buildings (Askari \& Kamariah, 2009; Fauziah et al., 2012; Kiruthiga \& Thirumaran, 2017). The visual quality of a historic building's facade determine the public's perception of visual elements in the facade, and the perception and feeling of someone who forms an assessment can be reflected in the physical environment (Mahmoudi, 2012). Determining perceptions of objects in the environment is very influential for the observer's point of view (Smardon, 1986). The purpose of visual perception is to explore and identify a variety of people's responses to obtain an assessment of an object.

Historic buildings the remaining in corridor sudirman the stone, done research on visual elements to historic buildings most influential facade. The purpose of this research is to find the elements most influential on the visual display facade building. Research on the visual facade Sudirman the historic buildings have research, so withdrawing to be researched. The focus of this study is the historic buildings visual facade and elements that exert influence over facade historic buildings. the Analyze how big the influence of visual on historic buildings elements facade and hopefully could fill cracks research and associated 
research topic story on elements to visual on facade building retaining with increased to made visual either as an asset heritage city.

\section{Methodology}

Using quantitative methods, the aim of this research was to know the community perceptions objectively with values in the form of numbers. Data is collected in two stages: (1) observation and (2) questionnaire. The observation was carried out at the initial stage to find out physical character. Used to know and the related facade community evaluation display the building via sheets questionnaire containing some of the questions to pictures object and research.

The research location was located in the Panglima Sudirman corridor, located in Pesanggrahan village, Batu. The length of Jalan Panglima Sudirman was about one and a half kilometres. The selection of research locations was also supported by the presence of around 20 historic ancient buildings scattered on this street. In the colonial period, the function of ancient buildings in the Sudirman Panglima corridor was dominated by residential functions.

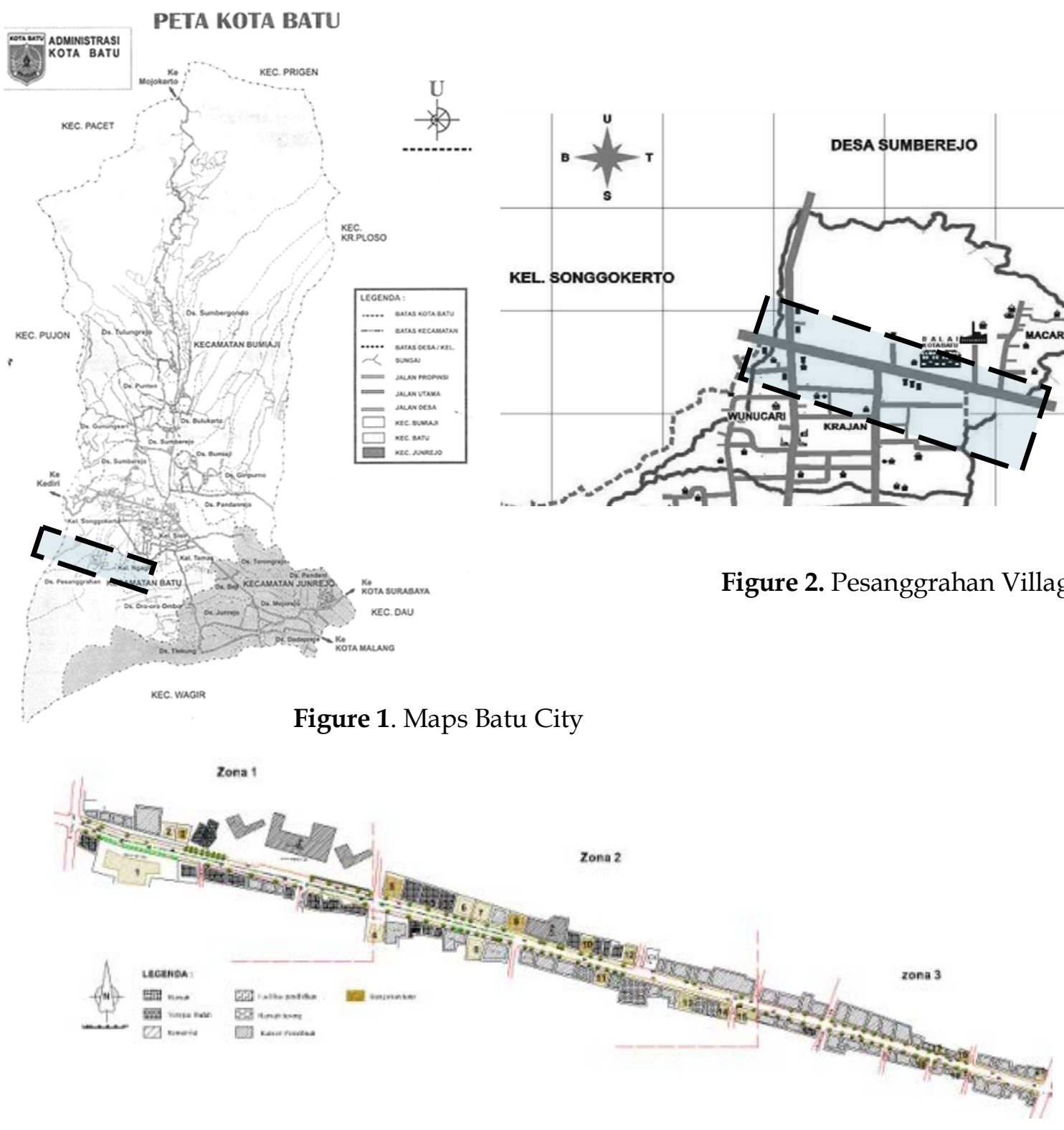


LOCAL WISDOM, Vol. 11 No. 2 July 2019

Local Wisdom Scientific Online Journal

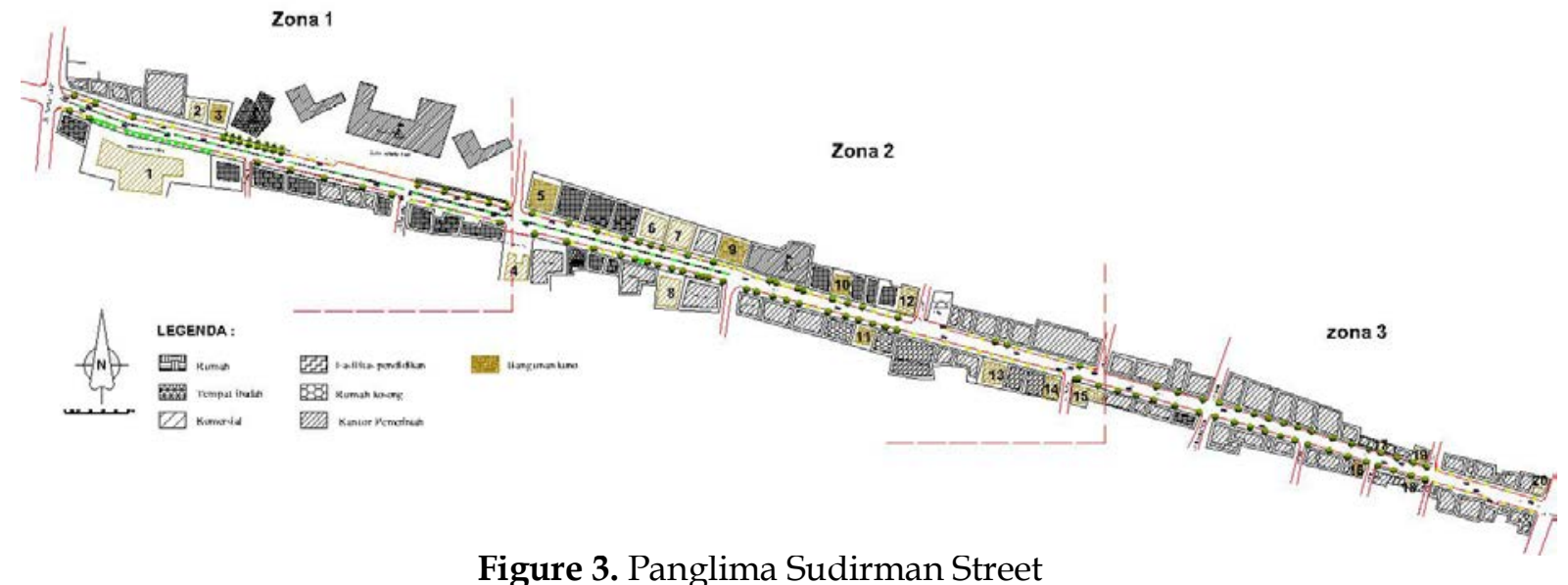

Figure 3. Panglima Sudirman Street

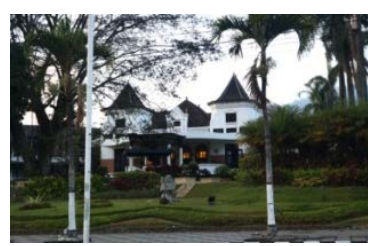

(1)

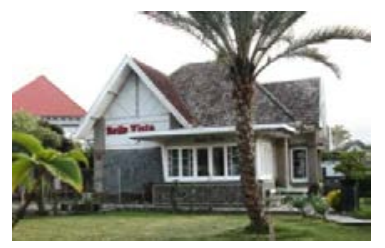

(5)

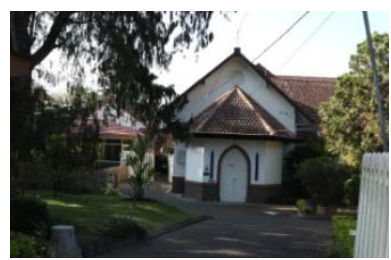

(9)

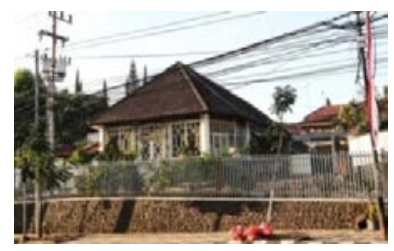

(13)

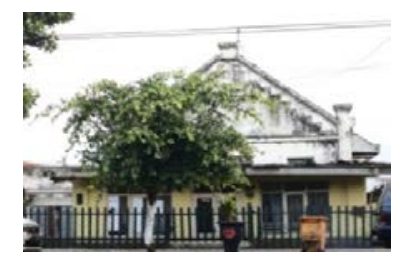

(17)

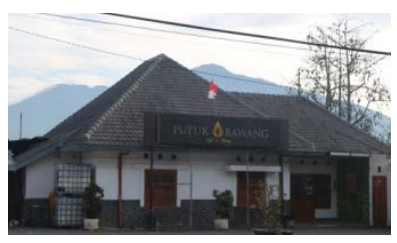

(2)

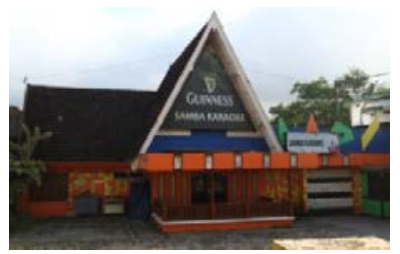

(6)

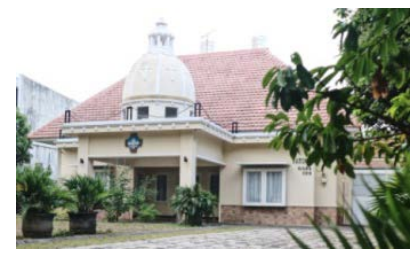

(10)

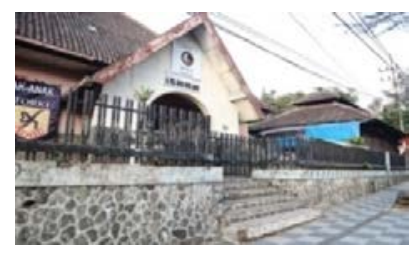

(14)

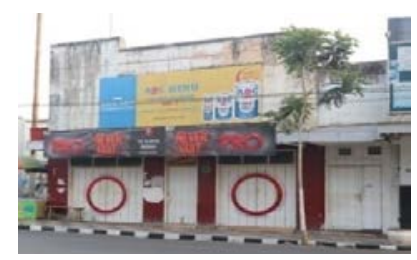

(18)

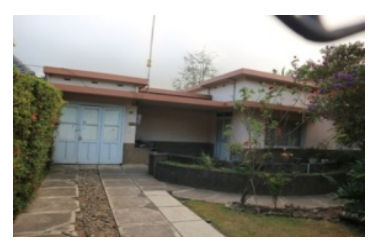

(3)

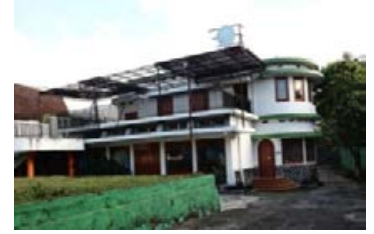

(7)

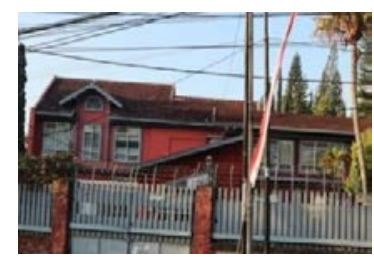

(11)

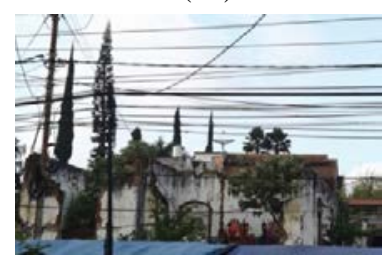

(15)

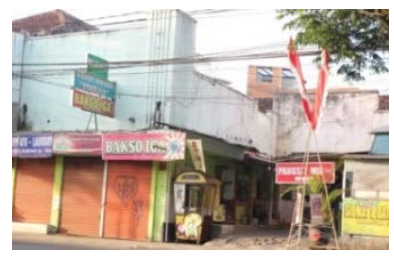

(19)

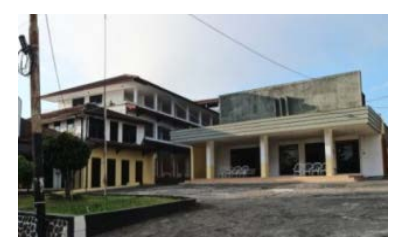

(4)

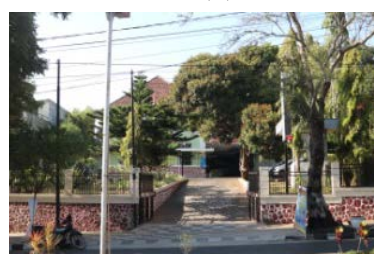

(8)

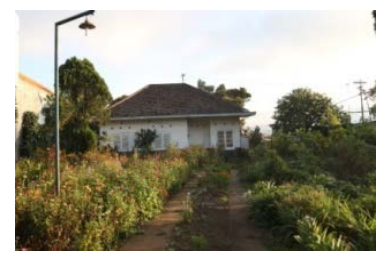

(12)

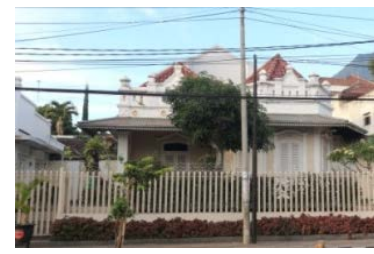

(16)

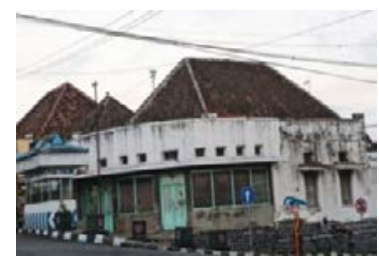

(20)

Figure 4. Historic Buidings 
The number of samples used in the study referred to the criteria of Hair, J. F., et al. (2010), and the number of samples used is 100 respondents. Respondents were randomly selected on the street. 100 Respondents were asked to give answers to questionnaires regarding the appearance of building facades. The distribution of the questionnaire was conducted from September to December 2018. The questionnaire was based on the seven scale Likert scale. Seven scales of answers ranged from "strongly agree" to "strongly disagree".

The research variables used in this study were based on the most dominant visual elements and are often studied in research related to visual assessment of building facades (Askari and Dola, 2009; Fauziah et al, 2012; Santosa et al, 2013):

1. Architectural Styles

2. Forms

3. Dimensions

4. Ornaments

5. Textures

6. Colours

Descriptive analysis was used to determine public perceptions of the visual quality of building facades, using the mean score. The results of the interval class measurements in this study are 3.78. Indicates if the respondent's score close to seven shows good results. The way to find the average value is to use SPSS software with a descriptive formula. Furthermore, regression analysis is used to determine the visual elements that affect the facade of historical buildings

\section{Results and Discussion}

Components of building facades included roofs, walls, columns, beams, room openings and ornaments. The visual elements in the building facade consist of 6 variables, which were architectural style, shape, colour, dimension, ornament and texture. In this study, the quality of the appearance of the facade of historical buildings was obtained through consideration of the average value. After evaluating the visual elements, the researchers proceeded to find out the relationship between visual elements and the facade of a historical building. Table 1 shows the results of a visual assessment of the historic building's facade.

Table 1. Assessment of building facades

\begin{tabular}{clcc} 
No & \multicolumn{1}{c}{ Visual Element } & Respondents & Mean Score \\
\hline 1 & Architectural Styles & 100 & 5.35 \\
\hline 2 & Forms & 100 & 5.03 \\
\hline 3 & Dimensions & 100 & 5.23 \\
\hline 4 & Ornaments & 100 & 5.25 \\
\hline 5 & Textures & 100 & 4.97 \\
\hline 6 & Colours & 100 & 4.64 \\
\hline & Mean Score & & 5.08 \\
\hline
\end{tabular}

Table 1 shows that the visual element assessment obtained an average between 4.64 and 5.35. From these results, the public perception of the appearance of building facades was between moderate to good. The architectural style showed the highest average value of the entire visual element with 5.35. Colour had the lowest average value (4.64). The average overall result of the assessment of the facade of a historic building is 5.08, which indicated good appearance. Next was to find out the most influential visual elements using S 20.0 regression analysis. The independent variable consisted of architectural styles, shapes, colours, dimensions, ornaments and textures while the dependent variable was the visual quality. 
LOCAL WISDOM, Vol. 11 No. 2 July 2019

Local Wisdom Scientific Online Journal

Table 2. ANOVA

\begin{tabular}{|c|c|c|c|c|c|c|}
\hline \multicolumn{7}{|c|}{ ANOVA $^{a}$} \\
\hline & Model & Sum of Squares & $\mathrm{df}$ & $\begin{array}{l}\text { Mean } \\
\text { Square }\end{array}$ & $\mathrm{F}$ & Sig. \\
\hline \multirow[t]{3}{*}{1} & Regression & 41.591 & 6 & 6.932 & 27.291 & $000^{b}$ \\
\hline & Residual & 23.622 & 93 & .254 & & \\
\hline & Total & 65.213 & 99 & & & \\
\hline
\end{tabular}

a. Dependent Variable: visual quality

b. Predictors: (Constant), architectural style, form, colour, dimension, texture, ornament

The ANOVA results show that the significance value is below 0.05 , indicating good results.

Tablel 3. Model Summary

Model Summaryb

\begin{tabular}{|c|c|c|c|c|}
\hline Model & $\mathrm{R}$ & R Square & $\begin{array}{l}\text { Adjusted R } \\
\text { Square }\end{array}$ & $\begin{array}{l}\text { Std. Error of } \\
\text { the Estimate }\end{array}$ \\
\hline 1 & $.799 a$ & .638 & .614 & .5039800 \\
\hline
\end{tabular}

a. Predictors: (Constant), architectural style, form, colour, dimension, texture, ornament

b. Dependent Variable: visual quality

The Model Summary table, Adjusted R Square value is $61.4 \%$. This value can be used to see the magnitude of the influence of visual elements on the facade of historical buildings. There are still $38.6 \%$ of other factors that affect the appearance of facades of historic buildings.

Table 4. Coefficients

\section{Coefficients ${ }^{\mathrm{a}}$}

\begin{tabular}{|c|c|c|c|c|c|c|}
\hline & Model & $\begin{array}{r}\text { Unstandarc } \\
\text { Coefficie }\end{array}$ & & $\begin{array}{l}\text { Standardized } \\
\text { Coefficients }\end{array}$ & $t$ & Sig. \\
\hline & 1970uct & B & $\begin{array}{l}\text { Std. } \\
\text { Error }\end{array}$ & Beta & & ig. \\
\hline 1 & (Constant) & 1.832 & .287 & & 6.383 & .000 \\
\hline & Gaya arsitektur & .292 & .070 & .473 & 4.204 & .000 \\
\hline & Bentuk & .248 & .054 & .395 & 4.589 & .000 \\
\hline & Warna & .046 & .068 & .067 & .671 & .504 \\
\hline & Dimensi & .041 & .077 & .055 & .540 & .591 \\
\hline & Ornamen & .001 & .067 & .001 & .014 & .989 \\
\hline & Material & -.063 & .074 & -.090 & -.849 & .398 \\
\hline
\end{tabular}

a. Dependent Variable: Kualitas visual

Based on the $\mathrm{R}$ value obtained from the summary table, the influence of visual elements on the building facade is $61.4 \%$. The coefficient table shows that there are two visual elements that have the most influence on the appearance of facades of historical buildings, indicated by the significance value smaller than 0.05 . The results of the regression analysis show that the 
most influential visual elements according to people's perceptions are the architectural style and the facade of the historical buildings on Panglima Sudirman Street, Batu City. According to public perceptions, the architectural style and form have an important role in the facade of the historical buildings of Panglima Sudirman, Batu. There are 20 ancient buildings with colonial architectural styles such as the Kartika Wijaya hotel, Simon stock building, Luxor shop and others. The architectural style depends on the age of buildings, shapes, openings, colours and materials used (Nasar et al. in Suri, 2013). The shape of the building facade consists of regular, curved and various shapes. Ancient buildings typically have an almost even shape, which is regular, curved and other various forms (a combination of various forms). Form processing can affect impressions of space (Judge and Utomo, 2008). Because the shape of the facade is the result of a manifestation of creativity from physical aspects can be observed and visually assessed. Architectural style and form are the visual elements that have the most influence on the appearance of facades, these results are in line with previous research (Askari and Dola, 2009; Saputra et al., 2016) which emphasize that architectural styles, shapes and dimensions are the most important visual elements of facades of historic buildings .

\section{Conclusion}

The facade of historic buildings often gives a visually attractive impression on an area. The facade of the building has an important role that can represent the character of a city. Jalan Panglima Sudirman is a historical area, with around 20 historic ancient buildings remaining and scattered on this street. The results of the perception of the community towards the appearance of a facade of historical Islamic buildings along the corridor Jalan Panglima Sudirman the city of stones all have within them the appearance of moderately to essentially and perfectly morally Sudirman style of architecture shows a value rata-rata the highest of the full range of elements visual, while the value of rata-rata the lowest is the colour. Although there are obvious reasons of the successive visual element has an important role too on the overhead a facade of historical Islamic buildings Jalan Panglima Sudirman the city of stone is a style of architecture and the form. If there are changes due to the presence of new buildings, it is expected adaptable to the architectural style of ancient buildings around. These results are expected to be able to find out the visual elements of building facades that need to be maintained and improved in order to make a good visual as a heritage asset of Batu city.

\section{Reference}

Askari Amir Hossein \& Kamariah Binti Dola. (2009). Influence Of Building Façade Visual Elements On Its Historical Image: Case Of Kuala Lumpur City, Malaysia. Journal Of Design And Built Environment Vol. 5.

Boedihardja Kinskij Yohannes., Antariksa \& Fadly Usman. (2010). Pelestarian Bangunan dan Lingkungan di Jalan Panglima Sudirman Kota Batu. Arsitektur e-Journal, Vol: 3 No.2

Dhama, A., Antariksa \& Edi Basuki. (2014). Pelestarian Kawasan dan Bangunan Kuno Bersejarah Pusat Kota Probolinggo. Arsitektur e-journal, Vol.7 No. 2.

Ernawati, J. and Moore, G. (2014). Tourists' And Residents' Impressions Of A Heritage Tourism Site: The Case Of Kampong Taman Sari, Indonesia. Archnet-Ijar, Volume 8 - Issue 3.

Fauziah Nur., Antariksa \& Jenny Ernawati. (2012). Kualitas Visual Facade Bangunan Modern Pasca Kolonial di Jalan Kayutangan Malang . Jurnal RUAS, Vol:10 N0. 2 
Field, Andy. (2009). Discovering Statistics Using SPSS. 316-346.

Hair, J. F., Black. W. C., Babin. B. J.; and Anderson. R. E. (2010), Multivariate Data Analysis, 7th ed. Pearson Prentice Hall, New Jersey.

Kiruthiga K \& K. Thirumaran. (2017). Visual Perception On The Architectural Elements Of The Built Heritage Of A Historic Temple Town: A Case Study Of Kumbakonam, India. Frontiers Of Architectural Research (2017).

Kurniawan. E. B, R Y A Putri and D K Wardhani. (2017). Building conservation base on assessment of facade quality on Basuki Rachmat Street, Malang. IOP Conf. Series: Earth and Environmental Science 70

Mahmoudi Mohadeseh. (2012). Physical Attributes Of Streetscape In The Inner City Of Kuala Lumpur: Case Study Of Bukit Bintang Street And Tun Perak Street. Disertasi Dipublikasikan. Kuala Lumpur: University Of Malaya

Murtomo Bambang Adji., Edy Darmawan \& Dea Shamara. (2016). Mapping Of Urban Texture On Interest Heritage Buildings In Semarang. MODUL Vol 16 No.2

Nasar Jack L. (1992). Environmental Aesthetic. Library Of Congress Cataloging In Publication Data. United States Of America

Nasution, S. (2012). Metode Research. Jakarta : Bumi Aksara

Oppong,R A., et al. (2017). Conservation and character-defining element of historical town. Frontiers of architecture research 2018

Pemerintah Kota Batu. (2011). Rencana Tata Ruang Wilayah. Kota Batu Tahun 2010-2030.

Santosa Herry ,Shinji Ikaruga \&Takeshi Kobayashi. (2013). Visual Evaluation Of Urban Commercial StreetscapeThrough Building Owners Judgment. Journal of Architecture and Planning 78691 pp 1995-2005 9

Saputra Muhammad Alfian R., ndang T. S. Darjosanjoto \& Josef Prijotomo. (2016). Visual Qualities Of Darmo Heritage Street Corridor In Surabaya, Indonesia . International Journal of Education and Research. Vol. 4 No. 6.

Suri Nur Sukma \& Agung Sugiri. (2015). Persepsi Dan Preferensi MasyarakatTerhadap Fasad Bangunan Di Koridor Jalan Ki Samaun Kota Tangerang. Tata Loka Vol:17 No. 3.

Tandon Meeta \& Vandana Sehgal. (2017). Traditional Indian Religious Streets: A Spatial Study Of The Streets Of Mathura. Frontiers of architectural research. 